\title{
Diagnostic Value of Serum Procalcitonin Level in HCV Cirrhotic Patients with Spontaneous Bacterial Peritonitis
}

Nader Farid Mostafa (MD) ${ }^{1}$, Islam Abdel Mawla Ammar ${ }^{1}$ (MD), Mohammed Farouk Ibrahim² (MD), Mahmoud Abdou Ahmed Ismail ${ }^{1 *}$ (M.B.B.CH)

*Corresponding Author:

Mahmoud Abdou Ahmed Ismail drmeshref@gmail.com

Received for publication February 24, 2020; Accepted March 12, 2020; Published online March 12, 2020.

Copyright 2020 The Authors published by Al-Azhar University, Faculty of Medicine, Cairo, Egypt. All rights reserved. This an openaccess article distributed under the legal terms, where it is permissible to download and share the work provided it is properly cited. The work cannot be changed in any way or used commercially.

doi:

10.21608/aimj.2020.22933.1103

Hepatology, Gastroenterology and Infectious Diseases ${ }^{l}$ Department and Clinical Pathology Department, Faculty of Medicine, Al-Azhar University Cairo, Egypt.

\begin{abstract}
Background: Early diagnosis and prompt treatment of spontaneous bacterial peritonitis (SBP) due to end-stage liver disease is vital to shorten hospital stays and reduce mortality. Many studies have explored the potential usefulness of serum procalcitonin (PCT) in predicting SBP.

Objective: to evaluate the overall diagnostic accuracy of PCT levels for identifying SBP due to end-stage liver disease.

Patient and Methods: A prospective case control study was conducted on 60 post-HCV cirrhotic patients and 20 normal individuals (54 M and 26 F), at internal medicine department, Zagazig General Hospital. Full history, routine, physical examination and special investigations were taking.

Results: The summary estimates for serum PCT in the diagnosis of SBP attributable to end stage liver disease were: sensitivity $95 \%$ and specificity $95 \%$. Serum PCT is a relatively sensitive and specific test for the identification of SBP. However, due to the limited high-quality studies available, medical decisions should be carefully made in the context of both PCT test results and other clinical findings including diagnostic paracentesis.

Conclusion: For our study we can concluded that: Serum Procalcitonin level can be used as a diagnostic test for rapid and accurate diagnosis of Spontaneous bacterial peritonitis in HCV cirrhotic patients with sensitivity and specificity about $95 \%$.

Key words: Diagnostic Accuracy, HCV Cirrhotic Patients, Serum Procalcitonin, Spontaneous Bacterial Peritonitis
\end{abstract}

Disclosure: The authors have no financial interest to declare in relation to the content of this article. The Article Processing Charge was paid for by the authors.

Authorship: All authors have a substantial contribution to the article.

\section{INTRODUCTION}

Hepatitis is an inflammatory condition of the liver that may be caused by a virus (viral hepatitis). When persisting for years, it may progress to lethal conditions, such as cirrhosis and hepatocellular carcinoma (HCC). Hepatitis $\mathrm{C}$ is also a systemic disease affecting the whole body causing a multitude of extrahepatic manifestations. Viral hepatitis is the seventh most frequent cause of death in the world, surpassing HIV. ${ }^{1}$ Among the five viral agents capable of causing hepatitis, hepatitis $\mathrm{C}$ virus (HCV) is one of the deadliest, causing some 400,000 deaths annually. ${ }^{2}$ Globally, there are an estimated 71 million people actively infected with $\mathrm{HCV}$, and 11-14 million of them reside in Europe. ${ }^{3}$

Bacterial infections account for significant morbidity and mortality in end-stage liver disease (ESLD) patients. Spontaneous bacterial peritonitis (SBP) is the most frequent and life-threatening infection in these patients. ${ }^{4}$ Cirrhotic patients with SBP frequently develop a rapidly progressive impairment in systemic hemodynamics, leading to severe renal and hepatic failure, aggravation of portal hypertension, encephalopathy, and death. ${ }^{5}$ When first described, its mortality exceeded $90 \%$, but it has been reduced to $20 \%$ with early diagnosis and treatment. ${ }^{6}$ Early diagnosis of SBP is essential in hospitalized patients with liver disease; however, this presents a challenge for clinicians because of the frequent lack of symptoms in the early stages of SBP. ${ }^{7}$ At present, most guidelines recommend that a diagnostic paracentesis should be performed in all patients with ascites admitted to hospital regardless of whether or not there is clinical suspicion. Diagnosis is established by an ascites polymorphonuclear cells 
(PMN) count $>250$ cells $/ \mathrm{mm}^{8}{ }^{8}$

Although paracentesis is usually a safe procedure, complications may occur from time to time. It has been reported that abdominal wall hematomas in $1 \%$ of patients, and even more severe complications such as hemoperitoneum or bowel penetration by the needle occurred in 1 case per 1000 paracenteses. ${ }^{9}$ In rare cases, pathogenic bacteria such as staphylococci can be introduced along with the needle to the ascites. It is therefore clear that using blood for routine examinations is more convenient and safer than ascitic fluid, and the measurement of serum biomarkers has consequently received much attention recently for the early diagnosis of SBP. ${ }^{10}$ Procalcitonin (PCT) is a precursor of calcitonin, normally secreted by $\mathrm{C}$ cells of the thyroid in healthy individuals. In the absence of infection, the extrathyroidal expression of the PCT gene in the liver, lung, kidney, adrenal tissue, monocytes, granulocytes, testis, prostate gland, and small intestine is suppressed. ${ }^{11}$ Procalcitonin in the blood of healthy individuals is below the limit of detection of clinical assays, but microbial infection, especially of bacterial origin, induces a ubiquitous increase in PCT gene expression, resulting in the constitutive release of PCT from parenchymal tissues throughout the body. In bacterial infections, serum PCT levels start to rise $4 \mathrm{~h}$ after the onset of systemic infection and peak between 8 and 24 h. 16 The half-life of PCT in serum is 20 to $24 \mathrm{~h}$, which makes it suitable for early detection and daily monitoring. ${ }^{11}$

\section{PATIENT AND METHODS}

A prospective case control study was conducted on 60 post-HCV cirrhotic patients and 20 normal individuals (54 M and $26 \mathrm{~F}$ ), at internal medicine department, Zagazig General Hospital. All subjects signed an informed written consent after explanation of the aim of the study and the study details. They were divided into four main groups: Group I: Included 20 post-HCV cirrhotic ascitic patients with Spontaneous bacterial peritonitis. Group II: Included 20 post-HCV cirrhotic ascitic patients without Spontaneous bacterial peritonitis. Group III: (negative control) Included 20 post-HCV cirrhotic patients without ascites. Group IV: (negative control) Included 20 normal individuals. The study was approved by the ethical committee of $\mathrm{Al}$ Azhar Faculty of Medicine and an informed consent obtained from all subjects before the study was commenced.

The subjects included in this study were selected according to inclusion and exclusion criteria. Inclusion criteria: Post-HCV cirrhotic patients. All patients and participants have normal kidney functions (serum urea and creatinine levels).Exclusion criteria: Patients who were coinfected with HBV, Patients with thrombosis of the portal or supra hepatic veins or IVC, Patients who have Other co- morbidity that might affect portal pressure, Patients with DM, HTN, CKD, thyroid diseases, and malignancy, Patients who had undergone surgery for the correction of portal hypertension, gastrectomy's, and/or vagotomies, Patients with any ongoing infection other than SBP,
Patients with ongoing ingestion of alcohol, patients with gastrointestinal malignancy, or hepatocellular carcinoma, patients who refuse to participate in the study and dropped out patients.

Method of Sampling: Sample size was calculated using computer sample block randomization type. Samples were obtained during routine investigations. 5 CC sample of venous blood drained by sterile syringes, put in a tube containing dipotassium EDTA reagent, the sample were shaken gently and analyzed by (Medonic 20, Sweden). All patients included in the study were subjected to:Complete history taking: which included past history of encephalopathy, SBP, hematemesis, hematochezia, melena, endoscopic or surgical intervention of varices, cardiac and chest symptoms. Full Clinical Examination: which included cardiac, chest, manifestations of chronic liver disease (such as jaundice, flapping tremors, lower limb edema, organomegaly or ascites).

Diagnostic paracentesis for ascites fluid analysis. (count of PMN), and culture (groups 1, 2). Urine analysis, Chest $\mathrm{x}$ ray.

Investigations: $\mathrm{HCV}$ IgG antibodies ( $\mathrm{HCV} \mathrm{Ab}$ ). Hepatitis B surface antigen (HBsAg).

Serum procalcitonin level. Complete blood picture $(\mathrm{CBC})$ : including hemoglobin concentration $(\mathrm{Hb} \%)$, red blood cells (RBCs), white blood cells (WBCs), platelet count using Sysmex KX-21 automatized hematology analyzer (Sysmex corporation, Japan).Liver profile: alanine aminotransferase (ALT), aspartate aminotransferase (AST), albumin, total bilirubin and direct bilirubin, prothrombin time and INR. measured using a bio chromatic (405- 510 $\mathrm{nm})$ rate technique. Renal function tests: including blood urea and serum creatinine using the open system autoanalyzer synchron CX5 (Beckman USA). Tumor markers: AFP.CRP and ESR. All patients were submitted to abdominal ultra-sonographic examination for the liver (size, surface, echogenicity, focal lesions and biliary tree), Portal and splenic vein diameters and patency, Splenic size, ascites, and abdominal masses.

Statistical Analysis: Results were tabulated and statistically analyzed by using a personal computer using MICROSOFT EXCEL 2016 and SPSS v. 21 (SPSS Inc., Chicago, IL, USA. Statistical analysis was done using: Descriptive: e.g. percentage (\%), mean and standard deviation. Analytical: that includes: ANOVA F test. A value of P less than 0.05 was considered statistically significant.

\section{RESULTS}

The average age was $58.2 \pm 6.1$ years for group 1, $60.3 \pm 4.4$ years for group $2,53.9 \pm 4.8$ years for group 3 , and $50.2 \pm 7.0$ years for group 4 . The majority of patients were males that represent $60 \%$ for group 1 , 
$70 \%$ for group 2, $65 \%$ for group 3 and $75 \%$ for group 4 , with no statistically significant difference ( $\mathrm{p}$-value $>0.05$ ) between all groups as regard age and gender, (Figure 1). Also, no definitive source of infection was found other than SBP for group 1 . While, ascetic fluid analysis and culture for patients in groups 1 and 2 revealed that all patients in group 1 have SBP (PMN count $>250 \mathrm{c} / \mathrm{mm}$, and all patients in group 2 have sterile ascites (PMN count $<250$ $\mathrm{c} / \mathrm{mm}$ and negative culture). As regard PCT results show that patients in group 1 whish have spontaneous bacterial peritonitis, $95 \%$ of them have serum procalcitonin positive and 5\% were negative, Patients and participants in groups 2,3,4 wish have sterile ascites or not ascetic or not cirrhotic respectively have serum procalcitonin negative in $95 \%$ of them and positive in $5 \%$.

\section{Tables}

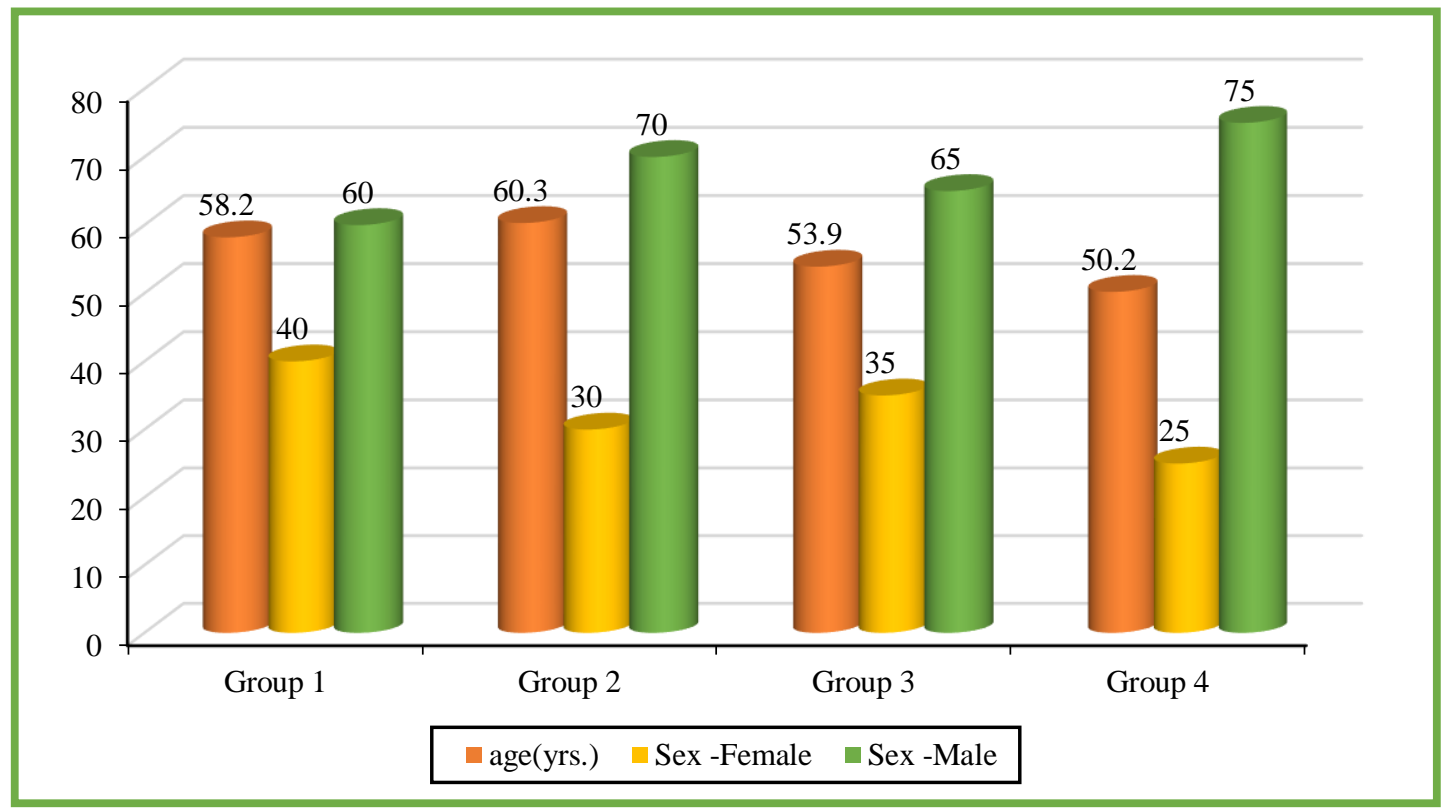

Fig. 1: Description of age and gender of studied patients and participants

\begin{tabular}{|c|c|c|c|c|c|c|c|c|c|c|}
\hline & & \multicolumn{2}{|c|}{ G1 } & \multicolumn{2}{|c|}{$\mathrm{G} 2$} & \multicolumn{2}{|c|}{ G3 } & \multicolumn{2}{|c|}{ G4 } & \multirow{2}{*}{$P$ value } \\
\hline & & No. & $\%$ & No. & $\%$ & No. & $\%$ & No. & $\%$ & \\
\hline \multirow{2}{*}{ us, liver } & Cirrhotic & 20 & 100.0 & 20 & 100.0 & 20 & 100.0 & 0 & 0.0 & \multirow{2}{*}{$<0.001$} \\
\hline & Normal & 0 & 0.0 & 0 & 0.0 & 0 & 0.0 & 20 & 100.0 & \\
\hline \multirow{2}{*}{ us/ ascites } & No & 0 & 0.0 & 0 & 0.0 & 20 & 100.0 & 20 & 100.0 & \multirow{2}{*}{$<0.001$} \\
\hline & Yes & 20 & 100.0 & 20 & 100.0 & 0 & 0.0 & 0 & 0.0 & \\
\hline \multirow{3}{*}{ us/ ascites } & No & 0 & 0.0 & 0 & 0.0 & 20 & 100.0 & 20 & 100.0 & \multirow{3}{*}{$<0.001$} \\
\hline & Moderate & 5 & 25.0 & 10 & 50.0 & 0 & 0.0 & 0 & 0.0 & \\
\hline & Tense & 15 & 75.0 & 10 & 50.0 & 0 & 0.0 & 0 & 0.0 & \\
\hline
\end{tabular}

Table 1: Description of U/S findings of studied patients and participants

Data presenting in table 1 shows that, Highly statistically significant difference ( $\mathrm{p}$-value $<0.001$ ) between groups 1 , 2, 3 and group 4 according to liver cirrhosis, and between groups 1,2 and groups 3, 4 according to ascites. The U/S findings of studied patients and participants. As regard liver, all patients of group 1, 2 and 3 are cirrhotic, and all participants of group 4 are normal. As regard ascites, 15 patients of group 1 have tense ascites and 5 have moderate ascites, 10 patients of group 2 have tense ascites and 10 have moderate ascites, and all patients and participants of group 3 and 4 are not ascitic. 


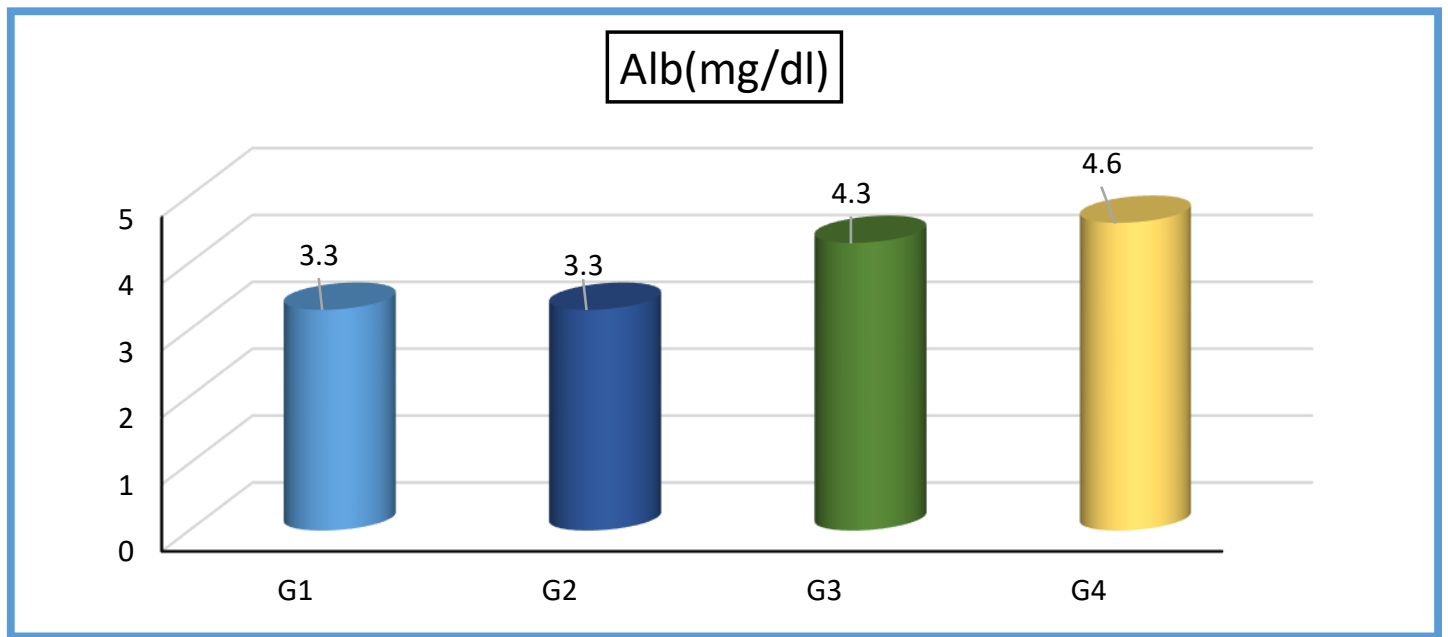

Fig. 2: Description of ALB of the studied patients and participants.

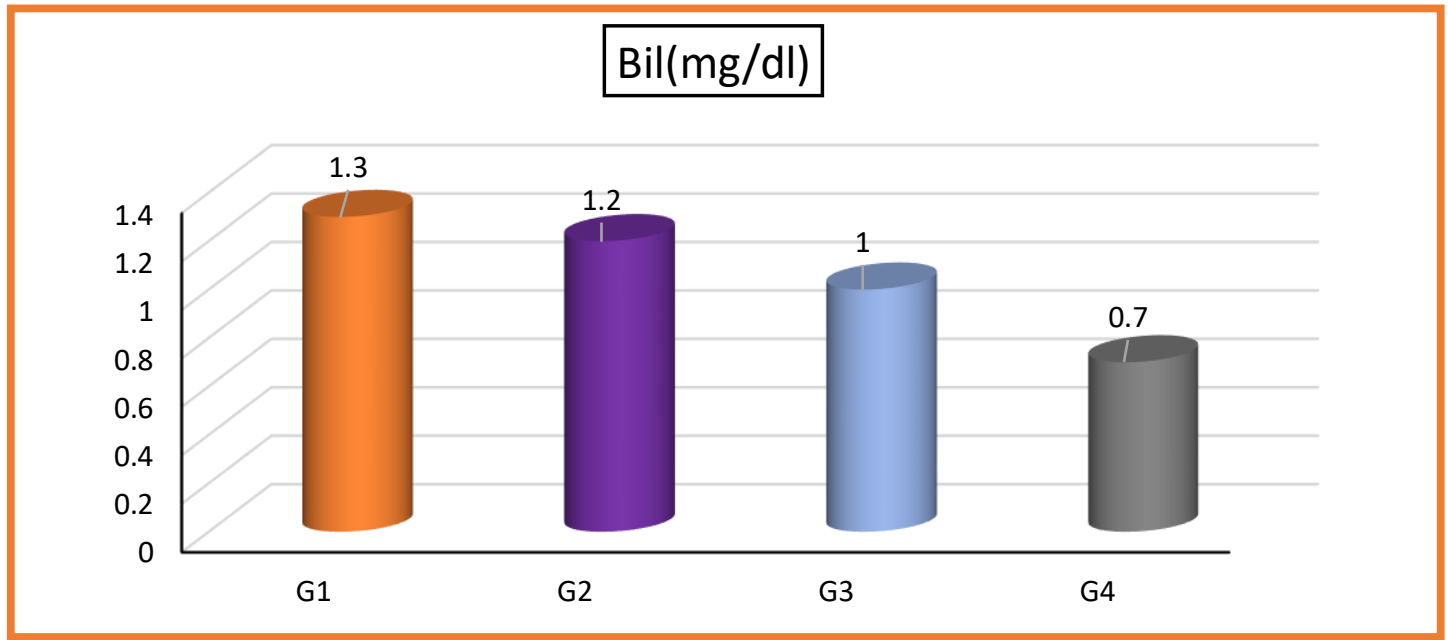

Fig. 3: Description of total of the studied patients and participants.

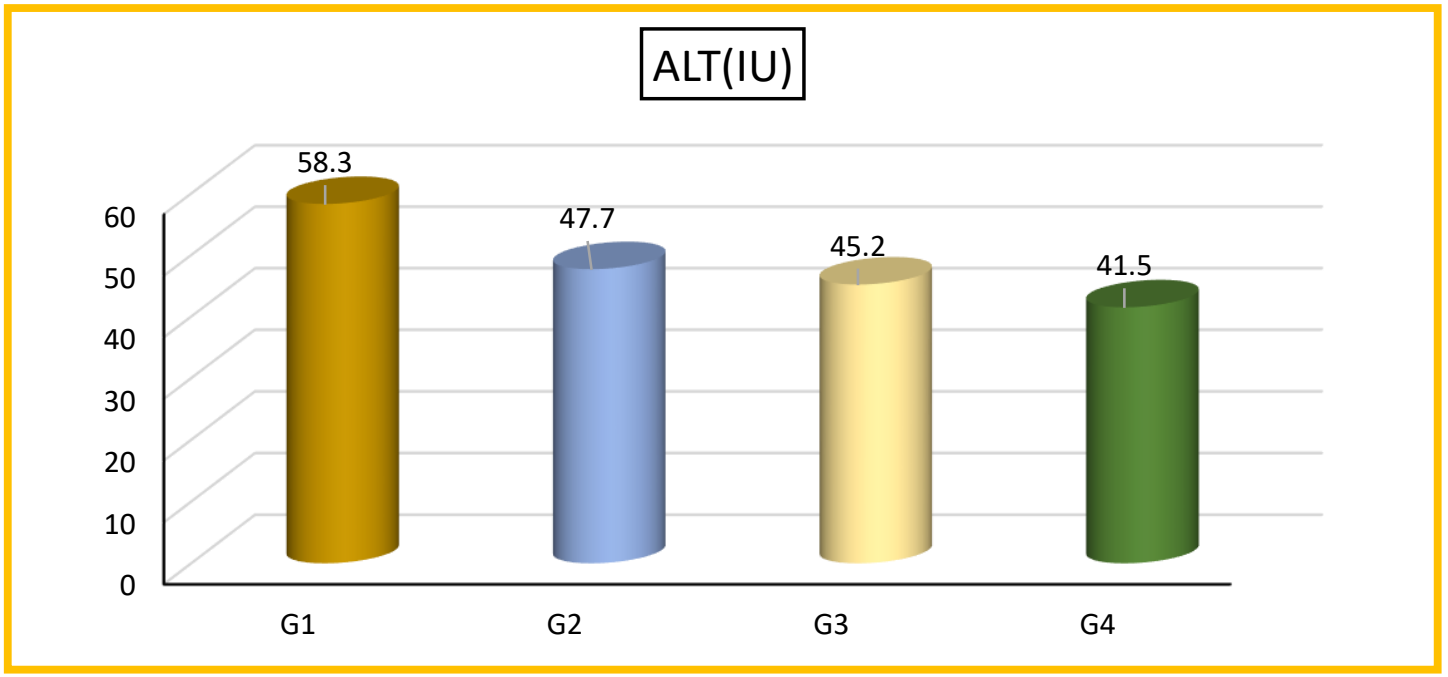

Fig. 4: Description of ALT of the studied patients and participants. 


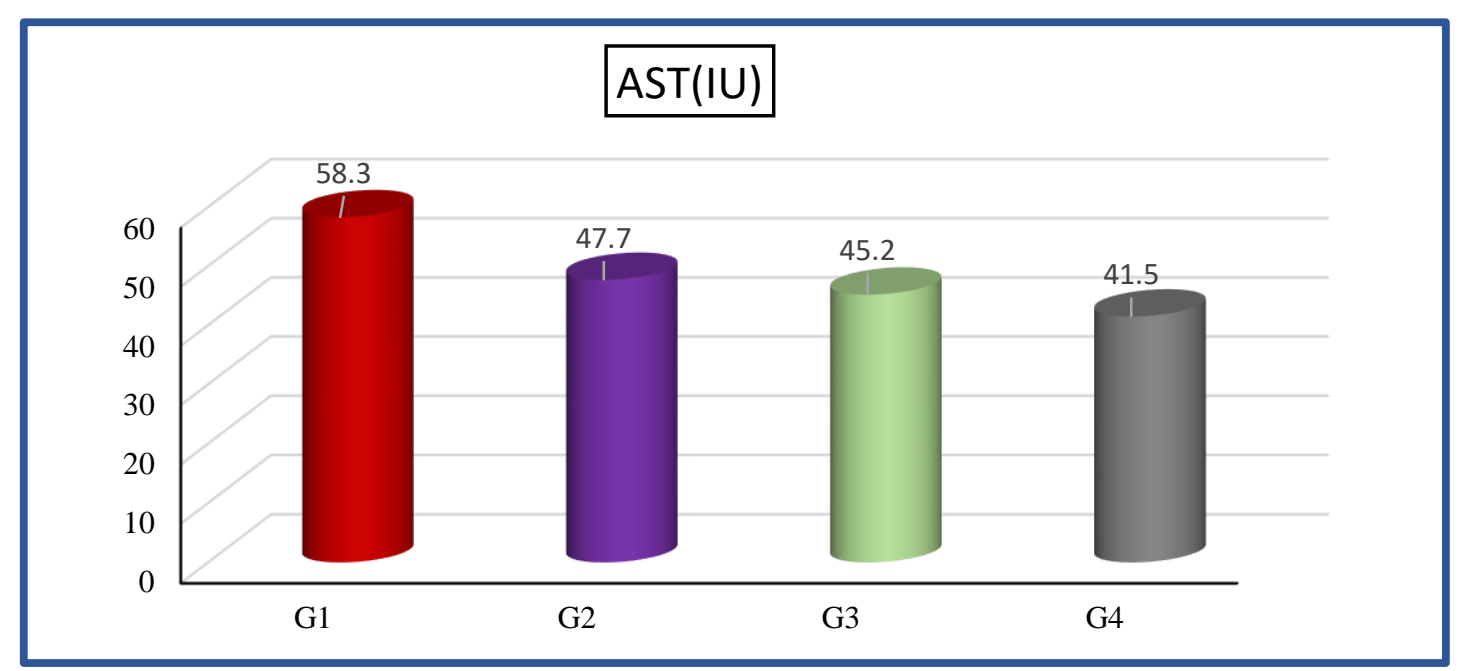

Fig. 5: Description of AST of the studied patients and participants.

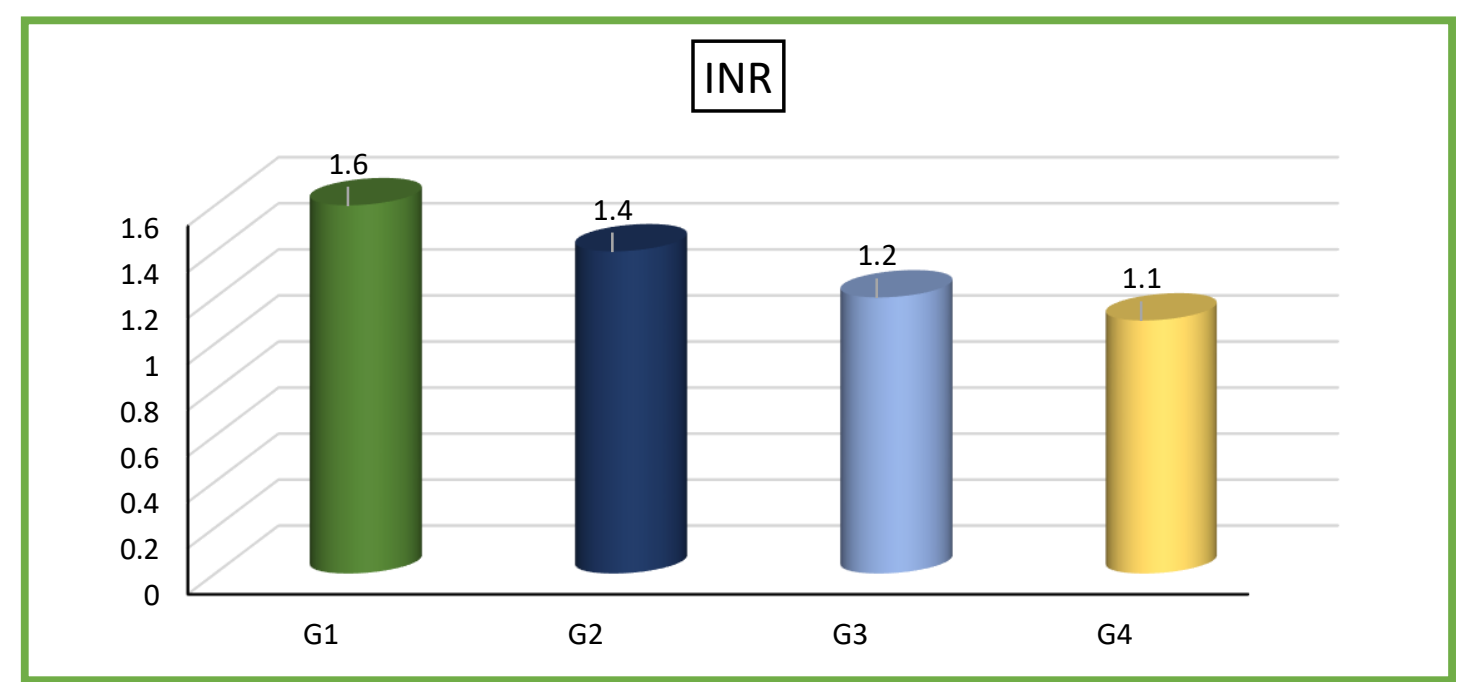

Fig. 6: Description of INR of the studied patients and participants.

\begin{tabular}{|c|c|c|c|c|c|c|c|c|c|c|}
\hline & & \multicolumn{2}{|c|}{ Group 1 } & \multicolumn{2}{|c|}{ Group 2 } & \multicolumn{2}{c|}{ Group 3 } & \multicolumn{2}{c|}{ Group 4 } & \\
\hline & & No. & $\%$ & No. & $\%$ & No. & $\%$ & No. & \% & p value \\
\hline $\begin{array}{c}\text { PCT } \\
\text { Results }\end{array}$ & Negative & 1 & 5.0 & 19 & 95.0 & 19 & 95.0 & 19 & 95.0 & $<0.001$ \\
& & & & & & & & & & \\
\cline { 2 - 11 } & Positive & $19^{\mathrm{a}}$ & 95.0 & 1 & 5.0 & 1 & 5.0 & 1 & 5.0 & \\
\hline
\end{tabular}

Table 2: Description of (PCT) results of the studied patients and participants.

Table 2 shows that Highly statistically significant difference (p-value $<0.001$ ) between all groups according to PCT. PCT is positive in $95 \%$ of patients of group 1, and negative in $95 \%$ of patients of group 2,3 and participants of group 4. 


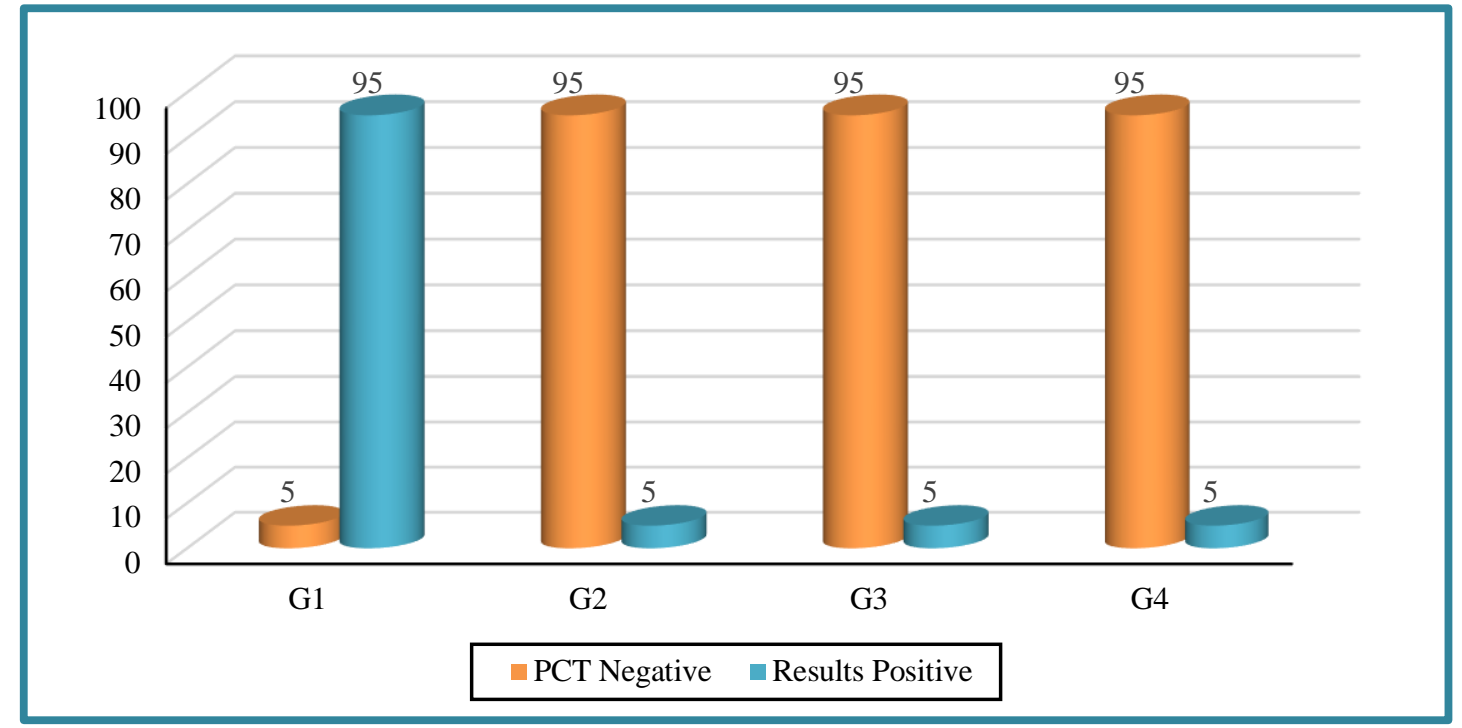

Fig. 7: Description of PCT results of the studied patients and participants.

\section{DISCUSSION}

Spontaneous bacterial peritonitis has been acknowledged as a potential trigger factor in many complications of cirrhosis, including variceal bleeding, hepatic encephalopathy, renal failure, and impairment in clotting factors, worsening hepatic status and leading to death in patients with cirrhosis. ${ }^{12}$ The usual absence of typical clinical characteristics in this patient population makes identification of SBP difficult. ${ }^{13}$ An ascitic PMN count $>250$ cells $/ \mathrm{mm} 3$ is considered diagnostic of SBP and triggers immediate initiation an empirical antibiotic treatment. $^{3}$

Spontaneous bacterial peritonitis caused by Grampositive cocci is associated with a PMN count below the threshold of 250 cells $/ \mathrm{mm} 3$, because the stimulatory capacity for PMN migration depends on the type of bacteria. The suitability of a range of biomarkers, such as serum C-reactive protein, PCT, lipopolysaccharidebinding protein, ascites leucocyte esterase activity, lactoferrin or bacterial DNA, to be used in rapid screening tests has been explored in many studies. ${ }^{12,14,15}$ At present, most guidelines recommend that a diagnostic paracentesis should be performed in all patients with ascites admitted to hospital regardless of whether or not there is clinical suspicion. Diagnosis is established by an ascites polymorphonuclear cells (PMN) count $>250$ cells $/ \mathrm{mm}^{8}{ }^{8}$

Although paracentesis is usually a safe procedure, complications may occur from time to time. It has been reported that abdominal wall hematomas in $>1 \%$ of patients, and even more severe complications such as hemoperitoneum or bowel penetration by the needle occurred in 1 case per 1000 paracenteses. ${ }^{9}$

Procalcitonin in the blood of healthy individuals is below the limit of detection of clinical assays, but microbial infection, especially of bacterial origin, induces an obvious increase in PCT gene expression, resulting in the constitutive release of PCT from parenchymal tissues throughout the body. In bacterial infections, serum PCT levels start to rise $4 \mathrm{~h}$ after the onset of systemic infection and peak between 8 and $24 \mathrm{~h} .16$ The half-life of PCT in serum is 20 to $24 \mathrm{~h}$, which makes it suitable for early detection and daily monitoring. ${ }^{11}$

This study was a case control study, and was conducted on 60 post-HCV cirrhotic patients and 20 normal individuals (54 M and $26 \mathrm{~F}$ ), at internal medicine department, Zagazig general hospital, it was designed for evaluation the role of serum procalcitonin level as rapid and safe diagnostic marker in hospital admitted cirrhotic ascitic patients. with spontaneous bacterial peritonitis.

The studied patients and participants were classified into four groups:

Group I: Included 20 post-HCV cirrhotic ascetic patients with Spontaneous bacterial peritonitis. Group II: Included 20 post-HCV cirrhotic ascitic patients without Spontaneous bacterial peritonitis. Group III:(negative control) Included 20 post-HCV cirrhotic patients without ascites. Group IV:(negative control) Included 20 normal individuals.

In the current study, the average age was $58.2 \pm 6.1$ years for group $1,60.3 \pm 4.4$ years for group $2,53.9 \pm 4.8$ years for group 3, and $50.2 \pm 7.0$ years for group 4 , with no statistically significant difference ( $\mathrm{p}$-value $>0.05$ ) between all groups as regard age. Also, the majority of patients were male, that represents $60 \%$ for group 1,70 $\%$ for group 2, $65 \%$ for group 3 and $75 \%$ for group 4 , with no statistically significant difference (p-value > 0.05 ) between all groups as regard gender.

As regard history, examination and investigations: no definitive source of infection was found other than SBP for group 1. As regard diagnostic paracentesis: ascetic fluid analysis and culture for patients in groups 1 and 2 revealed that all patients in group 1 have SBP (PMN count $>250 \mathrm{c} / \mathrm{mm}$., and all patients in group 2 have sterile ascites (PMN count $<250 \mathrm{c} / \mathrm{mm}$ and negative culture).

As regard PCT results show that: Patients in group 1 whish have spontaneous bacterial peritonitis, 95\% of them have serum procalcitonin positive and $5 \%$ were negative, Patients and participants in groups 2,3,4 wish have sterile ascites or not ascetic or not cirrhotic respectively have serum procalcitonin negative in $95 \%$ 
of them and positive in 5\%. Our results were in agreement with Yang, et al. ${ }^{10}$, who found that; Serum PCT is a relatively sensitive (95\%) and specific (95\%) test for the identification of SBP. However, due to the limited high-quality studies available, medical decisions should be carefully made in the context of both PCT test results and other clinical findings.

\section{CONCLUSION}

For our study we can concluded that, Serum Procalcitonin level can be used as a diagnostic test for rapid and accurate diagnosis of Spontaneous bacterial peritonitis in $\mathrm{HCV}$ cirrhotic patients with sensitivity and specificity about $95 \%$.

\section{REFERENCES}

1. Stanaway JD, Flaxman AD, Naghavi M, et al. The global burden of viral hepatitis from 1990 to 2013: findings from the Global Burden of Disease Study. The Lancet. 2013, 388(10049):1081-1088.

2. World Health Organization. Global Hepatitis Report.

http://apps.who.int/iris/bitstream/handle/10665/255 016/9789241565455-eng.pdf?sequence $=1, \quad 2016$, (accessed May 26, 2018)

3. Razavi H, Robbins S, Zeuzem S, et al. Hepatitis C virus prevalence and level of intervention required to achieve the WHO targets for elimination in the European Union by 2030: a modelling study. The Lancet Gastroenterology \& Hepatology. 2017, 2(5):325-336.

4. Wiest R, Krag A and Gerbes A. Spontaneous bacterial peritonitis: recent guidelines and beyond. Gut. 2012, 61: 297-310.

5. Elefsiniotis IS, Skounakis M, Vezali E, et al Clinical significance of serum procalcitonin levels in patients with acute or chronic liver disease. European journal of gastroenterology \& hepatology. 2006, 18(5):525-530.

6. Tandon P, and Garcia-Tsao G. Bacterial infections, sepsis and multiorgan failure in cirrhosis. Semen Liver Dis. . 2008, 28:26-42.

7. DellaVolpe JD, Garavaglia JM and Huang DT Management of complications of end-stage liver disease in the intensive care unit. Journal of intensive care medicine. 2016;31(2):94-103.

8. Runyon BA. Management of adult patients with ascites due to cirrhosis: an update. Hepatology. 2009, 49: 2087-2107.

9. De Gottardi A, Thévenot T, Spahr L, et al. Risk of complications after abdominal paracentesis in cirrhotic patients: a prospective study. Clinical Gastroenterology and Hepatology. 2009, 7(8):906909.

10. Yang Y, Li L, Qu C, et al. Diagnostic accuracy of serum procalcitonin for spontaneous bacterial peritonitis due to end-stage liver disease: a metaanalysis. Medicine. 2015, 94(49):23-29.

11. Rahimkhani M, Einollahi N, Daneshvar HK, et al. Survey of serum procalcitonin in cirrhotic patients. Acta Medica Iranica. 2013,2:153-156.

12. Papp M, Vitalis Z, Altorjay I, et al. Acute phase proteins in the diagnosis and prediction of cirrhosis associated bacterial infections. Liver International. 2012, 32(4):603-611.
13. Attar BM, George M, Ion-Nedelcu N, et al. Disease dependent qualitative and quantitative differences in the inflammatory response to ascites occurring in cirrhotics. World journal of hepatology. 6(2):85.

14. Tsiakalos A, Karatzaferis A, Ziakas P, et al. Acutephase proteins as indicators of bacterial infection in patients with cirrhosis. Liver International. 2009, 29(10):1538-1542.

15. Albillos A, de-la-Hera A and Alvarez-Mon M. Serum lipopolysaccharide binding protein prediction of severe bacterial infection in cirrhotic patients with ascites. Lancet. 2004, 363: 1608-1610.

16. Kibe S, Adams K and Barlow G. Diagnostic and prognostic biomarkers of sepsis in critical care. $J$ Antimicrob Chemother. 2011, 66(2): 33-40. 